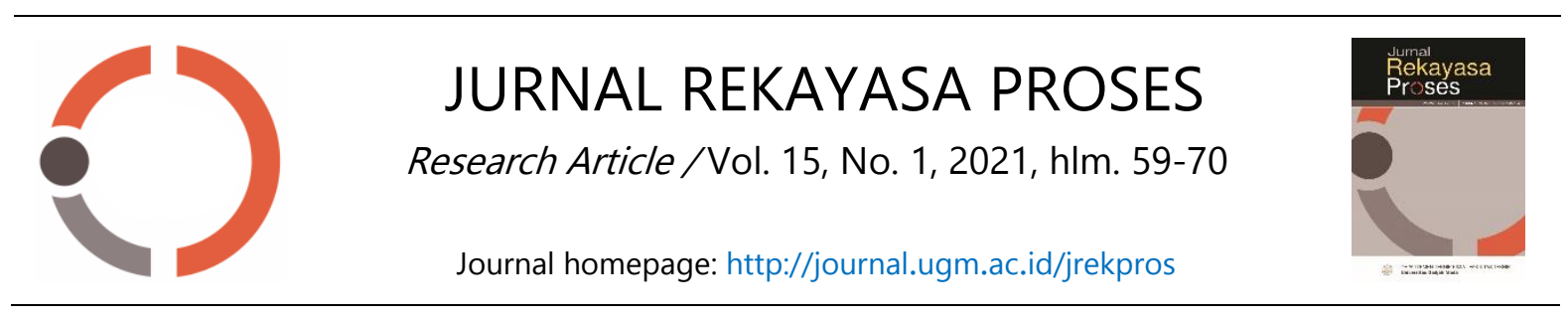

\title{
Kinerja Internal Reboiler Tipe Vertical Tubular Baffle pada Proses Distilasi Etanol secara Batch
}

\author{
Yuana Susmiati ${ }^{1,2^{\star}}$, Bambang Purwantana ${ }^{3 *}$, Nursigit Bintoro ${ }^{3}$ dan Sri Rahayoe ${ }^{3}$ \\ ${ }^{1}$ Ilmu Teknik Pertanian, Fakultas Teknologi Pertanian, Universitas Gadjah Mada \\ Jl. Flora No.1, Bulaksumur, Yogyakarta 55281, \\ ${ }^{2}$ Program Studi Teknik Energi Terbarukan, Jurusan Teknik, Politeknik Negeri Jember \\ Jl Mastrip no 164, Jember 68101, Jawa Timur \\ ${ }^{3}$ Departemen Teknik Pertanian dan Biosistem, Fakultas Teknologi Pertanian, Universitas \\ Gadjah Mada \\ Jl. Flora No.1, Bulaksumur, Yogyakarta 55281, \\ *Alamat korespondensi: yuanasusmiati@gmail.com (Y.S.); bambang_pw@ugm.ac.id (B.P)
}

(Submisi: 26 April 2021; Revisi: 26 Mei 2021; Penerimaan: 31 Mei 2021)

\section{ABSTRACT}

The performance of ethanol distillation is determined by the type of reboiler used in the distillation column. This study aims to determine the effect of differences in diameter and height of internal reboiler tubes, as well as feed content on ethanol distillate concentration and distillation yield. The research was conducted on a batch ethanol distillation process using a rectified distillation device with an internal vertical tubular baffle reboiler using different diameters and tube height, namely 1.5, 1, and 0.5 inches of diameter, and 8, 6, and $4 \mathrm{~cm}$ of tube heights. Materials or feeds in this study were ethanol solutions with levels of $10 \%, 20 \%$, and $30 \% \mathrm{v} / \mathrm{v}$. The results showed that the highest ethanol distillate content of $97.17 \% \mathrm{v} / \mathrm{V}$ (average) was achieved in the distillation process using an internal reboiler with a diameter of $0.5^{\prime \prime}$ a tube height of $8 \mathrm{~cm}$, and a feed content of $10 \%$. Geometry affected the heat transfer process in the internal reboiler of a distillation device so that it affected the distillation results.

Keywords: distillation; ethanol; internal reboiler: performance

\section{A B S T R A K}

Kinerja alat distilasi etanol ditentukan oleh jenis reboileryang digunakan pada kolom distilasi. Penelitian ini bertujuan untuk menentukan pengaruh perbedaan diameter dan tinggi tabung internal reboiler, serta kadar umpan terhadap kadar etanol distilat dan rendemen distilasi. Penelitian dilakukan pada proses distilasi etanol secara batch menggunakan alat distilasi rektifikasi dengan internal reboilerjenis Vertical Tubular Baffle yang berbeda ukuran diameter dan tinggi tabungnya, yaitu diameter 1,5, 1 dan 0,5 inci, serta tinggi tabung 8, 6 dan $4 \mathrm{~cm}$. Bahan atau umpan pada penelitian ini adalah larutan etanol berkadar $10 \%, 20 \%$ dan $30 \% \mathrm{v} / \mathrm{v}$. 
Hasil penelitian didapatkan kadar etanol distilat yang paling tinggi dengan kadar rata-rata $97,17 \% \mathrm{v} / \mathrm{v}$ dicapai pada proses distilasi dengan internal reboiler berukuran diameter 0,5 inci, dan tinggi tabung $8 \mathrm{~cm}$ dan kadar umpan 10\%. Geometri berpengaruh pada proses perpindahan panas di dalam internal reboiler suatu alat distilasi sehingga berpengaruh terhadap hasil distilasi.

Kata kunci: distilasi; etanol; internal reboiler; kinerja

\section{Pendahuluan}

Reboiler digunakan untuk menghasilkan uap yang mendorong terjadinya proses pemisahan dalam peralatan distilasi. Pada distilasi fraksinasi tradisional, semua energi pemisahan uap berasal dari reboiler. Oleh karena itu pengoperasian reboileryang tepat sangat penting untuk proses distilasi yang efektif (Tammami, 2008). Suhu reboiler menjadi salah satu faktor utama yang menentukan efisiensi proses distilasi etanol secara batch, dan perlu dikontrol karena berpengaruh terhadap produktivitas (Foletto, 2015). Distribusi suhu reboiler dipengaruhi oleh jenis reboiler yang digunakan dan merupakan faktor utama penentu nilai ekonomis proses. Pemilihan jenis reboiler ditentukan oleh faktor sifat fluida proses, tekanan operasi dan tata letak peralatan (Bhanvase dkk., 2007). Pemilihan jenis reboiler berarti menentukan metode sirkulasi fluida (termosifon, paksa, atau natural), dan memilih jenis penukar kalor (vertikal, horizontal, ketel atau internal). Penentuan ini dibutuhkan sebelum merancang bagian bawah di dalam menara distilasi, karena bentuk bagian dalam tersebut sangat tergantung dari jenis reboiler yang digunakan (Bell dkk., 2011).

Salah satu jenis reboiler yang digunakan pada alat distilasi adalah tipe internal reboiler, dan biasanya digunakan pada alat distilasi tradisional atau skala kecil. Menurut Bell dkk., (2011) dan Loraine A. H, (1999) internal reboiler yang dikenal dengan stab-in reboilers atau stab-in bundles merupakan bundel tabung penukar kalor yang dimasukkan langsung ke dalam menara bagian bawah dan terletak di bawah tray sehingga penukar kalor tersebut terendam fluida secara keseluruhan. Pada penelitian ini jenis reboileryang digunakan adalah internal reboiler yang dimodifikasi bentuknya dan dinamakan dengan tipe vertical tubular baffle. Reboiler ini menggunakan prinsip kerja penukar kalor jenis shell and tube di mana kolom menara bagian bawah sebagai shell dan beberapa tabung yang dipasang vertikal pada sebuah baffle sebagai tube. Bentuk reboiler yang vertikal dan hanya terdiri dari beberapa tabung diharapkan mampu memberikan perpindahan panas yang baik dan memudahkan pada proses konstruksi alat secara desain maupun biaya. Internal reboiler jenis ini berbeda bentuk dan arah pergerakan fluidanya jika dibandingkan dengan reboiler yang biasanya digunakan pada kolom distilasi skala kecil, di antaranya adalah tipe calandria, helix, dan bundel tabung horizontal (Susmiati dkk., 2019).

Perancangan termal pada penukar kalor tipe shell and tube biasanya mencakup penentuan luas perpindahan panas, jumlah tabung, panjang dan diameter tabung, tata letak tabung, susunan tabung, jumlah sekat, jenis dan ukurannya, jenis penukar kalornya (rangkaian tabung tetap atau bundel tabung 
yang dapat dilepas), juga penurunan tekanan sisi shell dan tabung (Nptel, 2006). Pada penukar kalor jenis shell and tube, dua fluida dengan temperatur berbeda mengalir melalui penukar kalor; satu mengalir melalui tabung (sisi tabung) dan aliran lainnya mengalir di luar tabung tetapi di dalam cangkang (shel/). Panas dipindahkan dari satu fluida ke fluida lainnya melalui dinding tabung, baik dari sisi tabung ke sisi cangkang atau sebaliknya (Bichkar dkk., 2018). Laju perpindahan panas pada penukar kalor shell and tube bergantung pada beberapa parameter seperti panjang tabung, jumlah sekat dan potongan sekat serta ditentukan oleh bilangan Reynolds dan Prandtl, pada kondisi aliran laminar maupun turbulen (Ranaware dkk., 2015).

Koefisien perpindahan panas dipengaruhi oleh geometri alat penukar panas, seperti penelitian yang dilakukan oleh Shirgire dkk., (2014) tentang keuntungan relatif penggunaan alat penukar kalor kumparan heliks terhadap alat penukar kalor pipa lurus. Pada penelitian tersebut ditemukan bahwa perpindahan panas dalam tabung lingkaran heliks lebih tinggi dibandingkan dengan tabung lurus karena faktor bentuknya. Pada penukar kalor jenis shell and tube, panjang tabung dianggap sebagai faktor penting dalam menyeimbangkan penurunan tekanan dan koefisien perpindahan panas. Bertambahnya panjang tabung meningkatkan tekanan operasi dan koefisien perpindahan panas secara keseluruhan karena luas penampang berbanding lurus dengan panjang tabung (Ali dkk., 2018). Percobaan yang lain dilakukan pada penukar kalor dengan diameter tabung tetap tetapi panjangnya berbeda sehingga ada variasi rasio L/D. Hasil eksperimen menunjukkan bahwa pada L/D yang berbeda, terjadi peningkatan perpindahan panas dengan adanya peningkatan panjang pipa (Roul dan Nayak, 2012).

Jenis reboiler serta bentuk dan ukuran tabung reboiler (geometri) sangat berpengaruh terhadap distribusi panas pada kolom distilasi dan berpengaruh terhadap produktivitas. Parhi dkk., (2019) menyatakan bahwa produksi tahunan pada proses distilasi batch campuran benzena dan toluena dapat berubah atau meningkat dengan mengoptimalkan masukan panas reboiler dan rasio refluks. Total produksi tahunan dapat ditingkatkan dan kebutuhan bahan baku dapat diturunkan secara signifikan dengan menggunakan kolom distilasi batch yang dioperasikan pada panas reboiler yang berubah-ubah dibandingkan dengan panas reboiler tetap. Badi dkk., (2001) juga menyatakan bahwa waktu retensi dan suhu reboiler pada proses regenerasi (distilasi) monoethylene glycol (MEG) berpengaruh terhadap produk degradasi MEG, yaitu asam organik. Selain itu, waktu retensi reboileryang lebih singkat memberikan produksi asam organik lebih kecil. Berdasarkan latar belakang tersebut, penelitian ini dilakukan untuk menentukan bagaimana pengaruh bentuk dan ukuran tabung dari internal reboiler tipe vertical tubular baffle yang digunakan pada kolom distilasi untuk proses pemurnian etanol secara batch terhadap hasil distilasi yang meliputi kadar etanol distilat dan rendemen distilasi.

\section{Metode Penelitian}

\subsection{Bahan Penelitian}

Pada penelitian ini, umpan atau bahan yang digunakan adalah etanol teknis $96 \% \mathrm{v} / \mathrm{v}$ dan aquades. Etanol teknis tersebut 
diencerkan menjadi etanol berkadar rendah 10\%, 20\% dan 30\% v/v. Proses distilasi dilakukan secara batch dengan alat distilasi rektifikasi skala laboratorium, yang dilengkapi reboiler berjenis internal Vertical Tubular Baffle dengan 9 jenis ukuran diameter dan tinggi tabung yaitu variasi diameter 1,5, 1 dan 0,5 inci dengan tinggi tabung 8,6 dan $4 \mathrm{~cm}$. Setiap proses distilasi menggunakan jenis internal reboiler yang ukuran diameter dan tinggi tabungnya berbeda, tetapi mempunyai luas permukaan yang sama, sehingga jumlah tabungnya berbeda-beda.

Alat distilasi terdiri dari komponen utama kondensor dengan panjang $32 \mathrm{~cm}$ dan diameter $6,35 \mathrm{~cm}$, kolom distilasi dengan panjang $76 \mathrm{~cm}$ dan diameter 5,08 cm, kolom reboiler dengan tinggi $30 \mathrm{~cm}$ dan diameter 20 $\mathrm{cm}$, dan boiler dengan tinggi $30 \mathrm{~cm}$ dan diameter $20 \mathrm{~cm}$. Jenis tray di dalam kolom distilasi adalah baffle tray, dengan irisan juring di salah satu sisinya yang disusun berseberangan satu sama lain sesuai dengan Gambar 1.

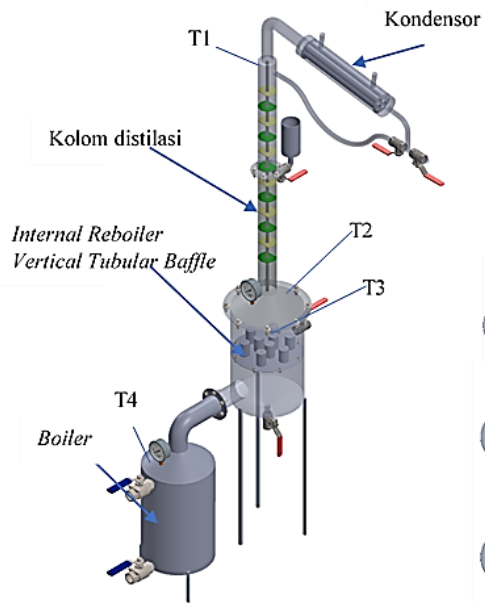

(a)

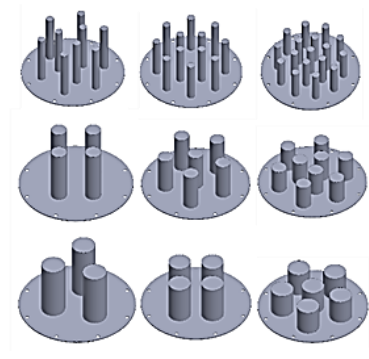

(b)
Gambar 1. (a) Alat distilasi rektifikasi skala laboratorium, (b) variasi internal reboiler tipe Vertical Tubular Baffle
Kadar etanol hasil distilasi diukur menggunakan metode piknometer sesuai Indian Standart Table for Alcoholmetry, Pyknometer Method (Kisan dkk., 1989). Alat yang digunakan pada pengukuran alkohol adalah piknometer dengan volume $10 \mathrm{ml}$ dan timbangan analitis dengan ketelitian 2 angka di belakang koma. Rendemen distilasi dihitung berdasarkan persamaan Sukasem dkk., (2017) yang ditampilkan pada Persamaan (1).

Rendemen distilasi $(\%)=\frac{\text { total volume distilat }}{\text { volume umpan }} \times 100(1)$

\subsection{Cara Penelitian}

Proses distilasi dilakukan dengan volume umpan yang sama pada masing-masing jenis reboiler, dan diulang tiga kali untuk setiap jenis. Proses distilasi dilakukan pada alat distilasi rektifikasi secara batch dengan volume umpan sebanyak $3.500 \mathrm{ml}$. Proses distilasi diawali dengan pemasukan umpan ke dalam kolom distilasi dan tertampung di dalam kolom reboiler secara bersamaan, dilanjutkan dengan pemanasan boiler dan diatur pada suhu $105{ }^{\circ} \mathrm{C}$. Suhu uap memasuki reboiler 97,4 ${ }^{\circ} \mathrm{C}$ (T4), yang kemudian memanaskan tabung-tabung reboiler dan panas tertransfer pada bahan yang ada di dalam reboiler sehingga suhu bahan tersebut meningkat dari $27{ }^{\circ} \mathrm{C}$ menjadi $83,9-96,2{ }^{\circ} \mathrm{C}$ (T3) dan bervariasi pada setiap jenis reboiler. Penguapan komponen volatil di dalam bahan terjadi di ruang reboiler dan suhunya 79,3 $92,9^{\circ} \mathrm{C}(\mathrm{T} 2)$, sehingga panas terus merambat ke kolom distilasi melalui baffle tray dan suhu di kolom bagian atas mencapai $56,4-79,8{ }^{\circ} \mathrm{C}$ (T1). Proses distilasi dihentikan pada waktu distilat sudah tidak menetes lagi yaitu ketika suhu di T1 menurun menjadi $45,37-67,67^{\circ} \mathrm{C}$. Distilat menetes dengan volume dan kadar 
etanol (komponen volatil) yang berubahubah. Distilat ditampung dan dikumpulkan selama proses distilasi, sehingga didapatkan volume distilat terakumulasi. Setelah proses selesai, residu berupa komponen tidak menguap yang terdapat di reboiler dikeluarkan secara bersamaan. Proses distilasi tersebut dikatakan sebagai distilasi batch sebagaimana disampaikan oleh Van Duc Long dkk., (2020). Proses ini berbeda dengan distilasi kontinyu yang memasukkan feed secara bertahap, mengeluarkan residu di kolom reboiler (bottom) secara bertahap, serta menghasilkan distilat dengan volume dan kadar secara tetap di setiap waktu.

Kadar etanol distilat merupakan kadar etanol yang diukur pada volume akumulasi hasil distilasi. Kadar etanol di distilat diukur pada akhir proses berlangsung, dan merupakan kadar etanol campuran hasil distilasi, menggunakan metode gravimetri/piknometer pada suhu $25{ }^{\circ} \mathrm{C}$. Rendemen distilasi ditentukan berdasarkan kadar distilasi pada volume akumulasi dan volume umpan. Data yang diperoleh selama penelitian dianalisis dengan SPSS 25 untuk mengetahui pengaruh perbedaan jenis reboiler terhadap parameter distilasi (kadar etanol distilat dan rendemen distilasi) dan penentuan jenis internal reboiler yang memberikan hasil tertinggi pada masingmasing parameter ditentukan dengan uji Duncan. Selain itu data dianalisis secara grafik untuk menunjukkan hubungan antara parameter penelitian (kadar etanol distilat dan rendemen distilasi) dengan perbandingan tinggi dan diameter tabung reboiler (L/D).

\section{Hasil dan Pembahasan}

Parameter kinerja alat distilasi tergantung pada ketersediaan panas atau NTU (number of transfer unit) dan efektivitas kinerja dari reboileryang berperan sebagai penukar kalor pada kolom distilasi. Sebagaimana disampaikan oleh (Foleto, 2015) bahwa suhu reboiler yang lebih tinggi menunjukkan laju penguapan cairan yang lebih tinggi dan menghasilkan laju aliran uap yang lebih tinggi.

Karakteristik perpindahan panas pada suatu alat penukar kalor ditunjukkan dengan besarnya koefisien perpindahan panas (Prasad dkk., 2013). Proses perpindahan panas pada penukar kalor terjadi karena adanya perbedaan temperatur pada suatu fluida yang mengalir pada tabung alat penukar kalor, sehingga terjadi perpindahan panas secara konveksi. Koefisien perpindahan panas dalam alat penukar kalor dipengaruhi oleh turbulensi, yaitu ketika turbulensi meningkat maka laju aliran massa fluida dan perpindahan panas juga meningkat (Gavade dkk., 2015).

\subsection{Kadar Etanol Distilat dengan Variasi Jenis Reboiler dan Umpan}

Hasil pengukuran kadar etanol distilat pada suhu $25{ }^{\circ} \mathrm{C}$ dari proses distilasi yang menggunakan jenis internal reboiler berbeda pada penelitian ini disajikan pada Tabel 1 . Data tersebut merupakan data rata-rata setiap variasi yang dilakukan 3 ulangan. Data kadar etanol distilat dianalisis statistik Anova dengan SPSS 25 untuk mengetahui pengaruh variasi perlakuan terhadap hasil yang didapatkan. Berdasarkan hasil analisis tersebut diketahui bahwa pada tingkat kepercayaan 95\%, perbedaan tinggi tabung reboiler berpengaruh nyata terhadap kadar 
etanol distilat. Sedangkan perbedaan diameter reboiler dan kadar etanol umpan berpengaruh sangat nyata terhadap kadar etanol distilat. Interaksi antara diameter dan kadar umpan juga berpengaruh sangat nyata terhadap kadar etanol distilat. Kadar etanol distilat yang tertinggi ditentukan berdasarkan uji Duncan dan diperoleh pada perlakuan diameter tabung 0,5 inci $(0,0127 \mathrm{~m})$, tinggi tabung $8 \mathrm{~cm}(0,08 \mathrm{~m})$, dan kadar etanol umpan $10 \%$. Hal itu menunjukkan bahwa semakin kecil diameter dan semakin tinggi tabung reboiler serta kadar umpan yang rendah memberikan kadar etanol distilat yang semakin tinggi.

Tabel 1. Kadar Etanol Distilat pada Berbagai Konsentrasi Umpan pada Suhu $25^{\circ} \mathrm{C}$

\begin{tabular}{ccccccc}
\hline D (m) & $L(m)$ & $L / D$ & $\begin{array}{c}N \\
\text { tabung }\end{array}$ & $\begin{array}{c}F ~ 10 \% \\
(\%)\end{array}$ & $\begin{array}{c}F \text { 20\% } \\
(\%)\end{array}$ & $\begin{array}{c}F 30 \% \\
(\%)\end{array}$ \\
\hline 0,0127 & 0,04 & 3,15 & 17 & 95,77 & 90,47 & 90,50 \\
& 0,06 & 4,72 & 12 & 97,23 & 90,73 & 90,83 \\
& 0,08 & 6,30 & 9 & 97,17 & 92,90 & 91,60 \\
0,0254 & 0,04 & 1,57 & 9 & 90,93 & 88,00 & 88,50 \\
& 0,06 & 2,36 & 6 & 90,23 & 87,63 & 88,23 \\
& 0,08 & 3,15 & 4 & 93,30 & 89,97 & 88,90 \\
0,0381 & 0,04 & 1,05 & 6 & 84,30 & 84,40 & 83,73 \\
& 0,06 & 1,57 & 4 & 83,70 & 84,90 & 84,77 \\
& 0,08 & 2,10 & 3 & 85,87 & 85,47 & 86,90 \\
\hline
\end{tabular}

Pada Tabel 1 ditunjukkan bahwa semakin kecil diameter tabung reboiler maka semakin tinggi kadar etanol distilat pada masingmasing perlakuan kadar umpan. Nilai tertinggi kadar etanol distilat pada semua variasi kadar etanol umpan terdapat pada diameter tabung 0,5 inci dengan tinggi tabung reboiler $8 \mathrm{~cm}$. Pada diameter tabung 0,5 inci, semakin tinggi tabung reboiler maka semakin tinggi pula kadar etanol distilat, karena pada tabung yang diameternya kecil dan panjang, nilai koefisien perpindahan panasnya lebih tinggi. Menurut Ali dkk.,
(2018) koefisien perpindahan panas dan penurunan tekanan bertambah dengan bertambahnya panjang tabung.

Terjadinya perpindahan panas pada penukar kalor merupakan akibat dari adanya perbedaan suhu, sehingga suhu dapat dikatakan sebagai faktor utama. Rata-rata suhu bahan di dalam reboiler dalam penelitian ini ditunjukkan pada Tabel 2 . Perubahan suhu bahan pada penukar kalor berpengaruh terhadap laju aliran massa fluida dan turbulensi yang terjadi suhingga berpengaruh terhadap koefisien perpindahan panas (Gavade, dkk., 2015).

Tabel 2. Rata-rata Suhu Bahan di dalam Reboiler pada Berbagai Konsentrasi Umpan

\begin{tabular}{ccccccc}
\hline $\mathrm{D}(\mathrm{m})$ & $\mathrm{L}(\mathrm{m})$ & $\mathrm{L} / \mathrm{D}$ & $\begin{array}{c}\mathrm{N} \\
\text { tabung }\end{array}$ & $\begin{array}{c}\mathrm{F} \mathrm{10 \%} \\
\left({ }^{\circ} \mathrm{C}\right)\end{array}$ & $\begin{array}{c}\mathrm{F} \mathrm{20 \%} \\
\left({ }^{\circ} \mathrm{C}\right)\end{array}$ & $\begin{array}{c}\mathrm{F} \mathrm{30 \%} \\
\left({ }^{\circ} \mathrm{C}\right)\end{array}$ \\
\hline 0,0127 & 0,04 & 3,15 & 17 & 93,43 & 91,21 & 89,68 \\
& 0,06 & 4,72 & 12 & 93,19 & 91,46 & 89,67 \\
& 0,08 & 6,3 & 9 & 93,25 & 91,14 & 89,47 \\
0,0254 & 0,04 & 1,57 & 9 & 94,53 & 92,12 & 90,42 \\
& 0,06 & 2,36 & 6 & 94,3 & 92,32 & 90,64 \\
& 0,08 & 3,15 & 4 & 94,01 & 91,82 & 90,09 \\
0,0381 & 0,04 & 1,05 & 6 & 94,44 & 92,08 & 90,69 \\
& 0,06 & 1,57 & 4 & 94,76 & 92,39 & 90,29 \\
& 0,08 & 2,1 & 3 & 94,53 & 92,47 & 90,17 \\
\hline
\end{tabular}

Berdasarkan data Tabel 2, pada masingmasing perlakuan kadar umpan, semakin besar diameter tabung reboilermaka semakin tinggi suhunya. Hal tersebut seperti yang disampaikan Alimoradi (2017) bahwa peningkatan diameter dan panjang tabung koil pada penukar kalor meningkatkan efektivitas area permukaan sehingga efektivitas termalnya meningkat. Mirgolbabaei (2018) juga menyatakan bahwa efek pengurangan luas permukaan kumparan penukar kalor dominan pada kenaikan koefisien perpindahan panas sehingga terjadi penurunan efektivitas penukar kalor yang 
konsisten. Semakin tinggi suhunya, semakin cepat penguapan komponen ringan (etanol) sehingga produktivitas meningkat (Foleto, 2015).

\subsection{Rendemen distilasi dengan Variasi Jenis Reboiler dan Umpan}

Rendemen distilasi dihitung berdasarkan Persamaan (1) di metode penelitian dan diukur pada suhu $25{ }^{\circ} \mathrm{C}$. Rendemen distilasi menunjukkan efisiensi proses distilasi. Semakin tinggi rendemen distilasi maka semakin efisien proses distilasi yang berlangsung. Data rata-rata rendemen distilasi pada penelitian tercantum pada Tabel 3. Penentuan pengaruh perbedaan diameter dan tinggi tabung reboiler serta kadar etanol umpan terhadap rendemen distilasi dianalisis dengan statistik Anova menggunakan SPSS 25. Berdasarkan hasil analisis tersebut, didapatkan bahwa perbedaan perlakuan diameter tabung, tinggi tabung, dan kadar umpan berpengaruh sangat nyata terhadap rendemen distilasi. Interaksi antara diameter dan kadar etanol umpan juga berpengaruh sangat nyata terhadap rendemen distilasi.

Tabel 3. Rendemen Distilasi pada Berbagai Konsentrasi Umpan pada Suhu $25^{\circ} \mathrm{C}$

\begin{tabular}{|c|c|c|c|c|c|c|}
\hline$D(m)$ & $L(m)$ & $\mathrm{L} / \mathrm{D}$ & $\begin{array}{c}\mathrm{N} \\
\text { tabung }\end{array}$ & $\begin{array}{c}\text { F 10\% } \\
\text { (\%) }\end{array}$ & $\begin{array}{c}\text { F } 20 \% \\
(\%)\end{array}$ & $\begin{array}{c}\text { F 30\% } \\
\text { (\%) }\end{array}$ \\
\hline \multirow[t]{3}{*}{0,0127} & 0,04 & 3,15 & 17 & 34,18 & 61,36 & 73,52 \\
\hline & 0,06 & 4,72 & 12 & 29,25 & 55,15 & 69,89 \\
\hline & 0,08 & 6,30 & 9 & 19,83 & 56,10 & 69,97 \\
\hline \multirow[t]{3}{*}{0,0254} & 0,04 & 1,57 & 9 & 51,99 & 69,28 & 77,39 \\
\hline & 0,06 & 2,36 & 6 & 46,12 & 69,31 & 77,30 \\
\hline & 0,08 & 3,15 & 4 & 45,44 & 69,74 & 75,21 \\
\hline \multirow[t]{3}{*}{0,0381} & 0,04 & 1,05 & 6 & 62,39 & 76,79 & 80,79 \\
\hline & 0,06 & 1,57 & 4 & 60,48 & 73,44 & 79,82 \\
\hline & 0,08 & 2,10 & 3 & 54,78 & 69,94 & 82,96 \\
\hline
\end{tabular}

Rendemen etanol tertinggi ditentukan berdasarkan uji Duncan pada perlakuan diameter tabung 1,5 inci $(0,0381 \mathrm{~m})$ tinggi tabung $4 \mathrm{~cm}(0,04 \mathrm{~m})$ dan kadar etanol umpan $30 \%$. Jika ditinjau dari kadar etanol umpan, rata-rata rendemen distilasi yang tinggi didapatkan pada kadar umpan 30\% pada semua variasi diameter dan tinggi tabung reboiler. Semakin tinggi kadar etanol umpan, dihasilkan rendemen distilasi yang semakin tinggi juga. Semakin tinggi kadar etanol umpan berarti semakin besar komponen yang mudah menguap sehingga volume distilat yang dihasilkan juga semakin banyak sehingga meningkatkan rendemen distilasi.

Pada Tabel 3 dapat diketahui bahwa diameter tabung reboiler 1,5 inci pada semua perlakuan memberikan nilai rata-rata rendemen distilasi tertinggi. Rendemen distilasi meningkat selaras dengan peningkatan diameter tabung reboiler. Secara umum tinggi tabung $4 \mathrm{~cm}$ memberikan nilai rendemen distilasi lebih tinggi dibandingkan dengan tinggi tabung $6 \mathrm{~cm}$ dan $8 \mathrm{~cm}$. Penguapan bahan di dalam kolom distilasi ditentukan oleh kecepatan perpindahan panas pada reboiler. Semakin tinggi kecepatan perpindahan panas pada reboiler, berarti semakin tinggi nilai koefisien perpindahan panasnya. Hasil penelitian menunjukkan bahwa bentuk, ukuran, dan susunan dari tabung reboiler berpengaruh terhadap koefisien perpindahan panas internal reboiler. Hal tersebut seperti yang disampaikan oleh Ranavare dkk., (2015) dan Shirgire dkk., (2014) bahwa koefisien perpindahan panas dipengaruhi oleh geometri alat penukar kalor. Rosa dkk., (2014) dan Rosa dkk., (2017) juga menyatakan bahwa koefisien perpindahan panas pada suatu penukar kalor merupakan fungsi Nusselt, Reynold dan Prandtl yang nilainya 
dipengaruhi oleh bentuk atau geometri dari alat tersebut.

Pada proses distilasi etanol, semakin cepat penguapan yang terjadi, komponen air yang terikut semakin banyak sehingga kadar etanolnya rendah, tetapi rendemennya tinggi. Sebagaimana ditunjukkan Tabel 1, 2 dan 3, pada masing-masing kadar umpan kenaikan diameter menurunkan kadar etanol distilat, meningkatkan suhu, dan meningkatkan rendemen distilasi.

\subsection{Hubungan antara Kadar Etanol Distilat dan Rendemen Distilasi dengan Rasio Panjang dan Diameter Tabung Reboiler}

Perbandingan tinggi dan diameter tabung reboiler (L/D) merupakan salah satu faktor yang berpengaruh terhadap perpindahan panas yang terjadi di dalam reboiler sehingga hal tersebut juga berpengaruh terhadap kadar etanol dan rendemen distilasi. Pada penelitian ini, nilai L/D merupakan nilai pada luas permukaan yang sama sehingga L/D di sini hanya menunjukkan variasi geometri. Pada luas permukaan yang sama, nilai L/D semakin besar jika semakin tinggi nilai $L$ pada nilai $D$ yang sama, dan semakin kecil nilai $D$ pada nilai $L$ yang sama. Nilai L/D bisa jadi sama dengan nilai $L$ dan $D$ yang berbeda, dan hal tersebut akan berpengaruh pada banyaknya tabung sehingga geometri berubah.

Perbedaan geometri pada penukar kalor tipe vertical tubular baffle memberikan performa yang berbeda pula. Tinggi, diameter, dan jumlah tabung berpengaruh terhadap nilai koefisien perpindahan panas secara keseluruhan. Pada luas permukaan yang sama dengan tinggi dan diameter tabung berbeda, koefisien perpindahan panas secara keseluruhan juga berbeda (Susmiati dkk., 2019). Pada luas area yang sama dengan bentuk yang berbeda, penyerapan panas pada suatu alat penukar kalor juga berbeda. Contohnya pada penukar kalor pipa lurus, dibutuhkan ukuran yang lebih besar sedangkan bentuk pipa helix lebih kompak untuk kecepatan perpindahan panas sama (Gurav, 2015).

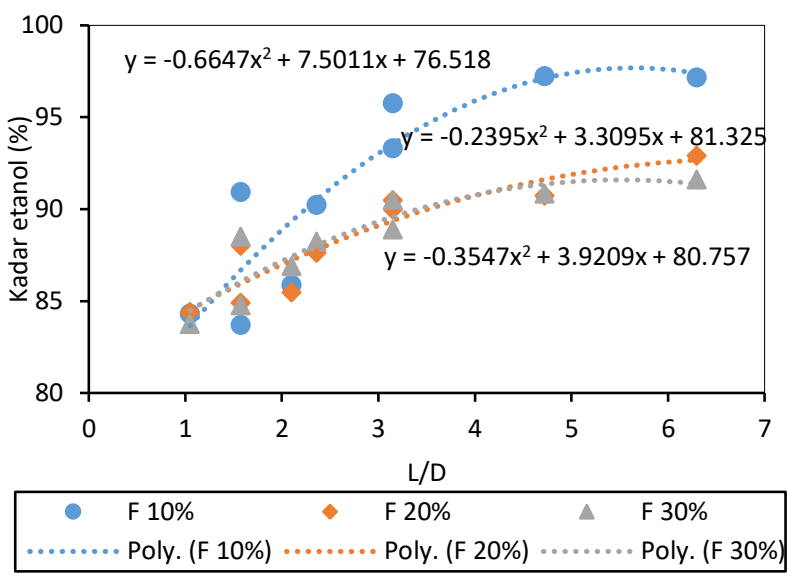

Gambar 2. Hubungan antara kadar etanol distilat dengan rasio L/D tabung reboiler

Hubungan antara kadar etanol distilat dengan L/D ditunjukkan pada Gambar 2. Secara umum semakin tinggi nilai L/D maka semakin tinggi juga kadar etanol distilat yang diperoleh pada semua perlakuan kadar etanol umpan. Tingginya nilai L/D juga terkait dengan banyaknya tabung reboiler. Semakin tinggi L/D semakin sedikit jumlah tabungnya dan pada diameter yang sama semakin tinggi ukuran tabung pada reboiler. Distribusi suhu pada penukar kalor dengan L/D yang berbeda untuk panjang pipa yang berbeda yang diamati oleh Roul dan Nayak (2012) menunjukkan terjadinya peningkatan perpindahan panas dengan peningkatan panjang pipa. Pada masing-masing kadar umpan L/D yang semakin tinggi suhu reboiler semakin rendah seperti yang ditunjukkan pada Tabel 2, sehingga komponen volatil 
(etanol) lebih banyak yang menguap karena titik didih etanol pada suhu $78{ }^{\circ} \mathrm{C}$. Suhu reboiler pada L/D yang tinggi mendekati titik didih etanol tersebut.

Berdasarkan Gambar 2, kadar etanol umpan $10 \%$ memberikan kadar etanol distilat lebih tinggi dibandingan dengan kadar etanol umpan $20 \%$ dan 30\%. Pada kadar umpan $10 \%$, suhu reboiler lebih tinggi dibandingkan dengan kadar umpan $20 \%$ dan $30 \%$ sehingga hampir semua komponen volatil yang ada menguap. Tingginya suhu pada reboiler dengan kadar 10\% juga dipengaruhi oleh viskositas larutan. Semakin banyak kadar etanolnya semakin tinggi viskositasnya dan semakin rendah suhunya. Turbulensi yang terjadi pada kadar umpan $10 \%$ lebih tinggi dibandingkan dengan kadar umpan lainnya. Peningkatan turbulensi mengakibatkan secara signifikan bercampurnya fluida di dalam tabung sehingga koefisien perpindahan panas meningkat (Gurav, 2015). Pada kadar etanol umpan 20\% dan 30\%, nilai kadar etanol distilat hampir sama, sehingga grafik terlihat berhimpit, dan nilai-nilai konstanta pada persamaan tidak terlalu jauh berbeda.

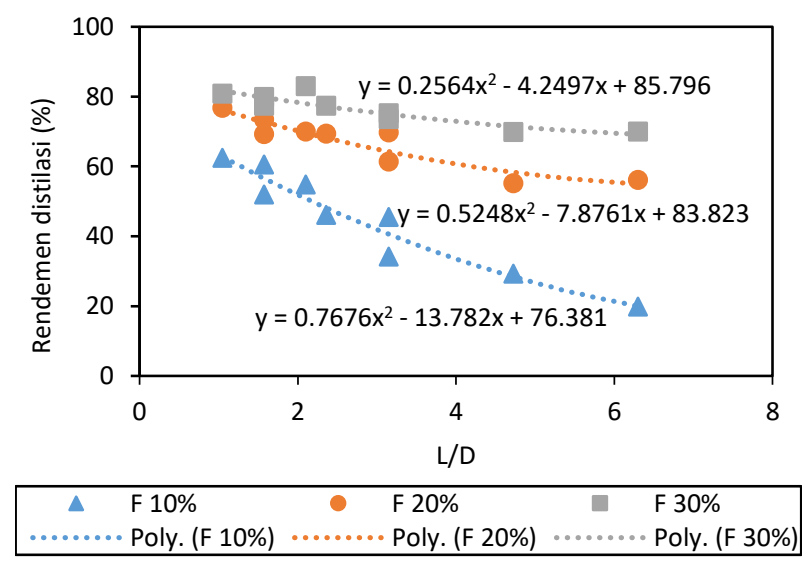

Gambar 3. Hubungan antara rendemen distilasi dengan rasio $L / D$ tabung reboiler
Rendemen distilasi juga dipengaruhi oleh perbandingan tinggi dan diameter tabung reboiler. Nampak pada Gambar 3, bahwa semakin tinggi nilai perbandingan tinggi dan diameter tabung reboiler (L/D) maka semakin rendah rendemen distilasi. Rendahnya rendemen distilasi disebabkan oleh semakin sedikitnya volume distilat yang didapatkan. Fenomena tersebut merupakan kebalikan dari kadar etanol distilat. Secara umum kadar etanol umpan $30 \%$ memberikan nilai rendemen distilasi lebih tinggi dibandingkan dengan kadar etanol umpan $10 \%$ dan $20 \%$. Pada kadar etanol umpan 10\% rendemen distilasi memberikan nilai paling rendah.

Kadar etanol distilat dan rendemen distilasi mempunyai kecenderungan nilai yang bertolak belakang pada masing-masing perlakuan. Kadar etanol umpan 10\% memberikan nilai kadar distilat paling tinggi, tetapi nilai rendemen distilasi yang paling rendah. Demikian juga sebaliknya kadar etanol 30\% memberikan nilai rendemen distilasi tertinggi, tetapi nilai kadar etanol distilat paling rendah. Kecenderungan nilai kadar etanol distilat terhadap L/D berbanding terbalik dengan nilai rendemen distilasi terhadap L/D. Secara umum, semakin besar L/D tabung reboiler maka semakin tinggi kadar etanol distilat, tetapi semakin rendah rendemen distilasi pada semua kadar etanol umpan.

Rendemen distilasi sangat tergantung pada banyak sedikitnya volume yang dihasilkan pada proses distilasi. Semakin tinggi kadar etanol umpan, maka semakin banyak komponen volatil yang mudah menguap, dan akan meningkatkan volume distilat. Semakin besar diameter dan semakin pendek tabung reboiler, maka semakin banyak air yang ikut menguap pada kolom 
distilasi sehingga semakin rendah kadar etanol distilat. Pada tabung yang rendah dan diameter yang lebar, turbulensi yang terjadi lebih tinggi, sehingga proses penguapan bahan lebih cepat dan banyak sehingga rendemen distilasinya tinggi. Sebaliknya pada tabung diameter kecil dan tinggi, fluida yang menempel pada tabung lebih banyak, dan air lebih banyak terkondensasi pada dinding tabung sedangkan yang menguap hanya bagian volatil saja. Hal tersebut meninggikan kadar etanol pada distilat. Pada kondisi tersebut, juga terdapat pengaruh bilangan Reynold yaitu bilangan Reynold meningkat dengan adanya peningkatan diameter pada kondisi fluida yang sama dan ditunjukkan dengan persamaan $R e=\frac{D \rho \vartheta}{\mu}$ dengan $\rho, \vartheta, \mu$, berturut-turut merupakan densitas, kecepatan dan viskositas bahan/fluida. Fouda dkk., (2018) menyatakan bahwa peningkatan bilangan Reynold dapat meningkatkan koefisien perpindahan panas keseluruhan. Perbedaan bilangan Reynold sangat dipengaruhi oleh perbedaan L/D dalam suatu penukar kalor tipe shell and tube, dan hal tersebut berpengaruh terhadap perpindahan panas (Aicher \& Martin, 1997). Perubahan pada parameter geometris dapat memberikan area pertukaran panas yang lebih tinggi (Fernández-seara dkk., 2014). Pada penelitian ini reboiler dengan luas area yang sama, perbedaan diameter dan tinggi tabung menyebabkan perbedaan jumlah tabung. Hal tersebut sesuai dengan pernyataan Feng dkk. (2019) bahwa kinerja pada penukar kalor shell and tube dapat ditingkatkan dengan pemilihan fluida kerja yang sesuai, laju aliran massa fluida panas, dan jumlah tabung.

\section{Kesimpulan}

Berdasarkan hasil penelitian, bentuk dan ukuran dari internal reboiler tipe vertical tubular baffle berpengaruh terhadap hasil distilasi. Kadar etanol hasil distilasi meningkat dengan meningkatnya rasio L/D tabung reboiler dan semakin rendah kadar etanol umpan maka semakin tinggi kadar etanol hasil distilasi. Kebalikannya rendemen distilasi menurun dengan adanya peningkatan rasio L/D dan semakin rendah kadar etanol umpan maka rendemen distilasi juga semakin rendah.

\section{Daftar Notasi}

$$
\begin{aligned}
& F=\text { jenis umpan }(\%) \\
& D=\text { diameter tabung reboiler (meter) } \\
& L=\text { tinggi tabung reboiler (meter) } \\
& N=\text { banyaknya tabung reboiler }
\end{aligned}
$$

\section{Ucapan Terima Kasih}

Penulis menyampaikan terima kasih kepada LPDP RI yang telah memberikan pendanaan pada studi dan penelitian ini dalam bentuk beasiswa BUDI-DN. Terimakasih disampaikan juga kepada Teknisi dan Pengelola Laboratorium Energi dan Mesin Pertanian Fakultas Teknologi Pertanian Universitas Gadjah Mada demi terselenggaranya penelitian ini.

\section{Daftar Pustaka}

Aicher, T., and Martin, H., 1997, New correlations for mixed turbulent natural and forced convection heat transfer in vertical tubes. Int. J. Heat Mass Transfer, 40(15), 3617-3626.

Ali, A., Qasim, M., and Zaki, S., 2018, Performance analysis of shell and tube heat exchanger: Parametric study, Case 
Studies in Thermal Engineering, 12, 563568.

Alimoradi, A., 2017, Study of thermal effectiveness and its relation with NTU in shell and helically coiled tube heat exchangers, Case Studies in Thermal Engineering, 9, 100-107

Badi, D., Al Helal, A., Lagat, C., Phan, C., and Barifcani, A., 2021, Evaluation of reboiler temperature retention time on MEG degradation products at varying MEG concentrations, J. Pet. Sci. Eng., 196, No. 107735.

https://doi.org/10.1016/j.petrol.2020.1077 35

Bell, J. A., Bouck, D., Farone, J. P., Flowers, J., Grave, E., Kister, H. Z. and Yeoman, N., 2011, Reboiler circuits for trayed columns, Chemical Engineering-Essentials for the CPI

Professional, https://www.chemengonline.com/reboiler -circuits-for-trayed-columns/

Bhanvase, B. A., Deosarkar, M. P., Shirsath, S. R., and Gaikwad, R. W., 2007, Internal reboiler in distillation column, Chemical Engineering World, 42(6), 86-88.

Bichkar, P., Ojas, D., Pranita, D., Rhushabh, G., and Dey, T., 2018, Study of shell and tube heat exchanger with the effect of types of baffles, Procedia Manufacturing, 20, 195200

Feng, H., Chen, L., Wu, Z., and Xie, Z., 2019, Constructal design of a shell-and-tube heat exchanger for organic fluid evaporation process. Int. J. Heat Mass Transfer, 131, 750-756.

Fernández-seara, J., Piñeiro-pontevedra, C., and Dopazo, J. A., 2014, On the performance of a vertical helical coil heat exchanger: Numerical model and experimental validation, Appl. Therm. Eng., 62 (2), 680-689

Foletto, E. L., 2015, Operation parameters of a small scale batch distillation column for hydrous ethanol fuel (HEF) production, Ingeniería e Investigación, 35(1), 31-35.

Fouda, A., Nada, S. A., Elattar, H. F., Refaey, H. A., and Bin-mahfouz, A. S., 2018, Thermal performance modeling of turbulent flow in multi tube in tube helically coiled heat exchangers, International Journal of Mechanical Sciences, 135, 621-638

Gavade, P. P., Malgave, S. S., Patil, D. D., Bhore, H. S., and Wadkar, V. V., 2015, Analysis of tube in tube helical coil and straight tube heat, Journal of Mechanical Engineering and Technology, 3 (2), 14-19.

Gurav, S. R., 2015, Parametric comparison of heat transfer in helical and straight tubein-tube heat exchanger, International Journal of Science and Research, 4(8), 2013-2016.

Kisan, M., Sangathan, S., Nehru, J., and Pitroda, S. G., 1989, Indian Standard Tables for Alcoholometry (Pyknometer Method) First Revision, Bureau of Indian Standards, New Delhi, June 1991.

Loraine A. Huchler, P. E., 1999, Managing Reboiler Steam-side Operation Improves Equipment Reliability and Steam Quality, MarTech Systems, Inc., Lawrenceville, New Jersey USA, p.17.

Mirgolbabaei, H., 2018, Numerical investigation of vertical helically coiled tube heat exchangers thermal performance, Appl. Therm. Eng., 136, 252259.

Nptel, 2006, Lecture 1: Heat Exchangers Classifications. Chemical Engineering Design - II, 1-41. 
Parhi, S. S., Rangaiah, G. P., and Jana, A. K., 2019, Optimizing reboiler duty and reflux ratio profiles of vapor recompressed batch distillation, Sep. Purif. Technol., 213, 553570.

Prasad, B., Sujith, V., K, M. S., Haneef, S., Sandeep, N., and Raj, V., 2013, Comparison of heat transfer between a helical and straight tube heat exchanger, Int. Journal of Engineering Research and Technology, $6(1), 33-40$.

Ranaware, N. D., Molawade, K. N., and Mane, L.N., 2015, A review on comparison between shell and tube heat exchanger and helical coil heat exchanger, International Journal of Innovations in Engineering Research and Technology, 2(2), 1-9.

Rosa, S., Moraes, M. S. De, To, J., Campos, D., and Toneli, L., 2014, External heat transfer coefficient in agitated vessels using a radial impeller and vertical tube baffles, Ind. Eng. Chem. Res., 53, 13797-

Rosa, S., Elena, M., Taqueda, S., Luis, J., Paiva, D., Silva, M., and Moraes, D., 2017, Nusselt's correlations in agitated tanks using the spiral coil with Rushton turbine and PBT $45^{\circ}$ impeller: Comparison with tanks containing vertical tube baffles, Appl. Therm. Eng., 110, 1331-1342.

Roul, M. K., and Nayak, R. C., 2012, Experimental investigaion of natural convection heat transfer through heated vertical tubes, Int. Journal of Engineering Research and Applications, 2(6), 10881096.
Shirgire, N. D., Thakur, A., and Singh, S., 2014, Comparative study and analysis between helical coil and straight tube heat exchanger, Int. Journal of Engineering Research and Applications, 4(8). 130-133

Sukasem, N., Hareemao, T., and Sudawong, C., 2017, The mimic of fractional distillation technology for development of homegrown pot distillery for ethanol distillation, Energy Procedia, 138, 985-990.

Susmiati, Y., Purwantana, B., Bintoro, N., Rahayoe, S., 2019, Design and testing of vertical tubular baffle heat exchanger as an internal reboiler in the distillation device, The 3rd International Symposium on Agricultural and Biosystem Engineering, IOP Conf. Series: Earth and Environmental Science, 355.

Tammami, B., 2008, How to select the best reboiler for your processing operation, Hydrocarbon Processing, 87(3), 91-94.

Van Duc Long, N., Lee, D. Y., Park, S. Y., Hwang, B. B., and Lee, M., 2020, HETP measurement using industrial-scale batch distillation, Chem. Eng. Process. - Process Intensification, 148, 107800. 